\section{EDUCATIONAL RECONSTRUCTION}

T HE long-awaited White Paper* setting forth in full the Government's policy and intentions in the matter of educational reform is now before the public, and will no doubt be discussed from every point of view. For the moment we confine ourselves to a summary of its principal proposals, reserving further comment for a later date. The cautious mode of procedure adopted by Mr. Butler commands general approval. The teachers, the administrators, the churches, the parents, and the existing local authorities may now know just where the Government stands, and are free to criticize before an Education Bill is introduced in Parliament. No one who recalls the stormy scenes of 1870 and 1902, and the fate of some of the best proposals of 1918, can wonder at Mr. Butler's studied patience and wariness. As in 1918, the fact that the coming Bill will be introduced on behalf of an all-party or non-party Government will facilitate its passage through Parliament, but it is to be hoped that it will do so with ultimately better results.

The Paper envisages national education in three stages--primary education, secondary education, and further education. The traditional term "elementary', which has long been a rather absurd anachronism, will now disappear from the official vocabulary. No longer will it be implied that teaching the 'elements' of the three $R$ 's is almost the raison d'être of the people's schools, and no longer will the parent's duty be confined to causing his child to be efficiently instructed in the three R's. His duty, as laid down in this Paper, will be "to cause his child to receive efficient full-time education suitable to the child's age and aptitudes" (par. 24).

Primary education is defined as covering the period up to eleven or twelve. The age for compulsory attendance at school, namely, five, will remain as now. Primary education is to include the nursery school, for children from two to five, the infants' school, for children between five and seven or eight, and the junior school, for children between seven or eight and eleven or twelve. Here we seem to have a convenient fixing of terminology which was necessarily left rather fluid in the Hadow Report on the primary school. There is now to be a comprehensive stage of primary education, of which the last part is the junior stage. As to nursery schools, the weak word "may" is to be replaced by the mighty word "shall". Otherwise expressed, "it is proposed to substitute for the present power of local education authorities a duty to provide, or aid the supply of, such nursery schools as in the opinion of the Board may be necessary". Good reasons are given for preferring self-contained nursery schools to nursery classes attached to infants' schools. Though no special prominence is given to the subject, the proposed provision for nursery schools is, for its social consequences, probably the most far-reaching thing in the whole document. Good reasons are again given for separate infants' and junior schools, wherever the numbers justify the arrangement. The psychological differences between the two stages are in general a part of "what every woman knows" and many men

" "Educational Reconstruction." Cmd. 6458. (London: H.M. Stationery Office, 1943.) $6 d$. net. also. The very large classes in many infant and junior schools are condemned unsparingly as affording "not education but mass production".

One of the most striking passages in the White Paper, also far-reaching in its educational consequences, is the condemnation (par. 17) of the present arrangements for transition from the junior schools to the post-primary schools. "There is nothing to be said in favour of a system which subjects children at the age of eleven to the strain of a competitive examination on which not only their future schooling but their future careers may depend. Apart from the effect on the children, there is the effect on the curriculum of the schools themselves. Instead of the junior schools performing their proper and highly important function of fostering the potentialities of children at an age when their minds are nimble and receptive, their curiosity strong, their imagination fertile and their spirits high, the curriculum is too often cramped and distorted by over-emphasis on examination subjects and on ways and means of defeating the examiners. The blame for this rests not with the teachers but with the system." So it is proposed to make a clean sweep of this unhealthy form of competition, a competition which is pernicious at any stage.

Coming now to secondary education, we observe that there are to be three types of secondary schools, to be known as grammar, modern and technical schools. The grammar school will be of the type represented by the present secondary schools, and the modern schools will be of the type represented by the existing central and senior schools. It is fully recognized that there are, in areas where re-organization has taken place, enormous differences between the two as to premises, equipment, staffing and what are called amenities but could often be more correctly described as decencies. Meantime the word 'secondary' is to be hopefully applied to both types, as well as to the technical schools, which have achieved so much success since they were started in 1905. The intention to raise the leaving age to fifteen without exceptions as soon as possible after the War, and to sixteen at a later date, will of course have an import. ant effect on secondary schools of all types. A child who is found, say; at the age of thirteen, to have been wrongly placed at the age of eleven may be transferred to a school more suitable for his bent and talents.

From the fact that religious education and the position of the voluntary schools occupy far more space than any other topic, amounting to nearly a quarter of the whole Paper, it may be inferred that the old difficulties have been fairly faced. One thing is clear. There is a very generai wish, not confined to representatives of the churches, that religious education should be given a more defined place in the life and work of the schools. The practice now prevailing in most primary and secondary schools of beginning the day with a corporate act of worship will now receive statutory sanction and be universal, but with due regard to the rights of conscience. In what we now know as provided schools the religious instruction will usually be in accordance with an agreed syllabus. No unwilling teacher will be compelled to give such instruction, and no teacher will be penalized for not giving it. Also, it is at last recog. nized that there is no valid reason why different principles should be applied to inspectors and teachers. The inspection will be limited to agreed syllabus instruction. As we have intimated, much space is 
devoted to the embarrassing dual system, including its history, and the reasons why the simple solution reached in Scotland is inapplicable south of the Tweed. A plan is described by which the degree of public control will be approximately proportioned to the amount of financial support provided from public funds.

The principles of the Act of 1918 relating to day continuation schools are to be adopted to meet the requirements of the post-war world, but the term "day continuation school" is to be abandoned, and the institutions required for the purpose will be referred to generally as 'young people's colleges'. "It is important," says the Paper, "to make clear that what is in view is no 'going back to school', a mere extension on a part-time basis of previous full-time schooling, but the entry on a new phase of life and development." Certain basic elements will be included in the training, and when these have been met the remaining hours may be devoted to a variety of subjects according to the needs and capacities of each individual.

The field covered by the term "further education" is obviously a wide one. The provision of further education is at present a power and not a duty of local authorities, and despite what many authorities have done, technical education has not made the advance which the needs of a highly industrialized community demand. To some extent the industries themselves are alive to the need of ordered systems of training, and by consultation with the Board of Education and the Ministry of Labour it is hoped to build up in each major industry a system which will be accepted and applied not by individual firms here and there, but on a national basis throughout the industry.

The White Paper emphasizes that without provision for adult education the national system must be incomplete. After all has been said about other forms of education, it is "within the wider sphere of adult education that an ultimate training in democratic citizenship must be sought". While the more serious and solid studies that have formed the backbone of adult education at its best must be maintained, there will be room for new methods and new approaches to meet new demands. Upon this question the education services that have operated. in the Forces have thrown much light.

Mention is made in the Paper of the Youth Service brought into being to extend the recreational training of young people by assisting the voluntary organizations. In spite of the restrictions imposed by war conditions on the supply of leaders, premises and equipment, the service has shown a remarkable expansion. "There is now a far higher proportion than at any previous time of young people associated with healthy leisure-time training and recreation without compulsion or regimentation of any sort." The section on health service, we may add, extends existing facilities for securing the physical wellbeing of children and young persons.

On the subject of access to the universities, it is noted that the path of the poor scholar has been made broader and less difficult during the last twenty years, and that the expenditure by the Board through thie system of State scholarships and by the local education authorities through their major awards has been a profitable investment, judged by the successes achieved by the beneficiaries. None the less, the system is inadequate. Again the difference between giving a power and laying a duty upon a local authority obtrudes itself, leading to a wide disparity in the opportunities of poor students. Upon this question the Norwood Committee's advice is now available for the guidance of the Government. The Paper hints that this is not the only direction from which provision may be made for highly promising persons after the War.

At various points in the course of the Paper the reader is reminded that legislation can do little more than prepare the way for reform. "It will rest with the Board and the local authorities, and, not least, with the teachers working in the schools, to translate its aims into practice." All along the line, through primary and secondary and further education, it is obvious that more, a great many more, teachers will be needed. But, says the Paper, it is not merely a larger number of teachers that will be required, but a larger number of the right kind. "It would be deplorable if the necessary corps of teachers could be obtained only at the expense of lowering existing standards. It depends almost entirely upon the quality of those who staff the schools whether the reforms proposed will be merely administrative reforms or whether they will, in practice, work out as real educational reforms." These questions of the supply and training of teachers are being investigated by the MeNair Committee, and the recommendations of that Committee are awaited. Meantime the Paper points out frankly what is "patently wrong" with the present system of recruiting and training teachers, and some of the reasons why an expert inquiry was long overdue. The field of recruitment is narrowly limited to those boys and girls who remain at grammar schools until 17 or 18 , and the educa. tional history of teachers is nearly all of one uniform pattern. As to the period immediately following the War, "there are many men and women now serving in the Forces or elsewhere whose experience and devotion would greatly enrich the education of children".

The Paper concludes with some plain speaking on the subject of "independent schools", that is, schools which stand apart from the State system. The expression includes all manner of establishments, from those which are excellent to those which, according to the report of a Departmental Committee in 1931-2, are so defective as to be harmful to the physical and mental welfare of the children, and those - a larger number - which are seriously deficient and inefficient. At present anybody, whatever his or her qualifications, can start an independent school in any building and, unless the use of the building constitutes a nuisance under the public health acts, its improvement or closure cannot be obtained. The Paper proposes that all independent schools must be open to inspection by the Board and registered on a list kept by them, and that schools found to be defective shall be suitably dealt with. It is characteristic of our national feeling in such matters that, in order to ensure that reasonable liberty shall remain for those schools outside the public system, the proprietor of a condemned school will have the right to appeal to an independent tribunal against the Board's decision.

Such are the main contents of a document, remarkable alike for its comprehensiveness and its lucidity, which will provide thoughtful citizens, both young and old, with food for thought during the next few months. No doubt much of further interest and value will accrue from the Parliamentary debates which will follow. 